\title{
Patryk Ciok
}

Uniwersytet Mikołaja Kopernika, Toruń

ciok.patryk@gmail.com

\section{Przedawnienie \\ roszczeń cywilnoprawnych \\ a zatarcie skazania w prawie karnym \\ na tle prywatnych rejestrów dłużników \\ w Polsce \\ - uwagi de lege lata i de lege ferenda}

DOI: http://dx.doi.org/10.12775/SIT.2016.002

Przedawnienie cywilnoprawnych roszczeń majątkowych stanowi instytucję prawa cywilnego, której istotą jest udzielenie dłużnikowi ochrony prawnej względem bezczynnego wierzyciela. Jej podstawowym założeniem jest to, że w związku z długotrwałym brakiem aktywnego działania wierzyciela, mającego na celu realizację przysługujących mu wierzytelności, ustawodawca uszczupla jego dotychczasowe możliwości przymusowego wyegzekwowania należnego świadczenia. Biorąc zaś pod uwagę tak zarysowaną istotę instytucji przedawnienia, za dość kontrowersyjną można uznać dopuszczalność ujawniania zobowiązań naturalnych (a więc zobowiązań powstałych $\mathrm{w}$ następstwie przedawnienia roszczenia) $\mathrm{w}$ rejestrach długów prowadzonych przez tzw. biura informacji gospodarczej.

Obecnie obowiązujące regulacje normatywne w żaden sposób nie zabraniają zgłaszania przedawnionych roszczeń do podobne- 
go rodzaju rejestru długów. Bywa to częstokroć wykorzystywane przez np. przedsiębiorstwa windykacyjne do wymuszania spłaty przedawnionych zobowiązan. W obecnych realiach społecznych omawiany problem dotyczy w szczególnej mierze konsumentów. $Z$ uwagi zaś na stosunkowo niewielką popularność publicznych rejestrów dłużników w niniejszym opracowaniu skupimy się przede wszystkim na roli rejestrów dłużników prowadzonych przez prywatne biura informacji gospodarczej.

\title{
1. Uwagi wprowadzające w zakresie instytucji przedawnienia roszczeń cywilnoprawnych oraz działalności biur informacji gospodarczej w Polsce
}

\author{
1.1. Podstawowe konsekwencje \\ przedawnienia roszczenia cywilnoprawnego
}

Instytucja przedawnienia to jedna $\mathrm{z}$ podstawowych instytucji, do których odnosi się pojęcie tzw. dawności, obejmujące wszystkie te instytucje prawa cywilnego, które wiążą skutki prawne $z$ upływem czasu $^{1}$. Skutkiem przedawnienia roszczeń majątkowych $\mathrm{w}$ polskim prawie cywilnym pozostaje zaś przede wszystkim przekształcenie zobowiązania w tzw. zobowiązanie naturalne, cechujące się znacznym osłabieniem ochrony prawnej przysługującej wierzycielowi $z$ jego tytułu. $Z$ jednej strony zatem jej zadaniem pozostaje przede wszystkim motywowanie wierzyciela do jak najszybszego egzekwowania przysługujących mu roszczeń i ochrona dłużnika przed nadmiernie przeciągającym się stanem niepewności co do swojej sytuacji prawnej. $Z$ drugiej natomiast strony instytucja ta ma za zadanie realizację postulatu pewności obrotu prawnego. Znaczący upływ czasu od momentu powstania zobowiązania czy wymagalności wynikającego $z$ niego roszczenia rodzić może bowiem choćby poważne trudności w zakresie choćby kwestii do-

1 A. Wolter, J. Ignatowicz, K. Stefaniuk, Prawo cywilne, Warszawa 1996, s. 319. 
wodowych ${ }^{2}$. Umożliwienie wierzycielom egzekwowania przysługujących im roszczeń bez stawiania im jakichkolwiek ograniczeń temporalnych mogłoby zaś skutkować istnieniem „trwałych i nierozwiązywalnych stosunków prawnych" między określonymi podmiotami ${ }^{3}$, które $z$ pewnością stanowiłyby niekorzystne zjawisko z punktu widzenia pewności obrotu cywilnoprawnego.

W stosunku do innych zobowiązań cywilnoprawnych zobowiązanie naturalne wyróżnia przede wszystkim to, że dłużnik nie ponosi na ich podstawie odpowiedzialności za swój dług. Innymi słowy wierzyciel nie może skorzystać z pomocy organu państwowego w celu przymusowego wyegzekwowania roszczenia, a ujmując to inaczej $-\mathrm{z}$ zasady $\mathrm{w}$ razie podejmowania prób przymusowego wyegzekwowania roszczenia dłużnik dysponuje możliwością uchylenia się od jego zaspokojenia ${ }^{4}$. Samo zobowiązanie w dalszym ciągu pozostaje prawnie istniejące, natomiast spełnienie świadczenia $z$ jego tytułu nie daje podstawy do żądania zwrotu przedmiotu świadczenia w oparciu o instytucję bezpodstawnego wzbogacenia. Jeśli jednak wolą dłużnika będzie odmowa zaspokojenia takiego roszczenia, ma on do tego pełne prawo, podnosząc tzw. zarzut przedawnienia, paraliżując tym samym dążenia wierzyciela. W ewentualnym procesie sądowym efektem byłoby zaś oddalenie powództwa skierowanego przeciwko dłużnikowi.

\subsection{Podstawy normatywne}

ujawniania informacji o dłużnikach za pośrednictwem biur informacji gospodarczej

Działalność polegająca na upublicznianiu informacji o dłużnikach i ich zaległych zobowiązaniach pieniężnych zajmują się tzw. biu-

2 P. Sobolewski, Tytuł VI. Przedawnienie roszczeń, w: Kodeks cywilny. Komentarz, t. 1, red. K. Osajda, Warszawa 2013, s. 880.

3 Wyrok TK z dnia 1 września 2006 r., SK 14/05, OTK-A 2008, Nr 8, poz. 97.

4 Z. Radwański, A. Olejniczak, Zobowiązania - część ogólna, Warszawa 2014, s. 22 . 
ra informacji gospodarczej (w skrócie BIG), na podstawie ustawy z dnia $z$ dnia 9 kwietnia 2010 r. o udostępnianiu informacji gospodarczych i wymianie danych gospodarczych ${ }^{5}$. Sama ustawa nie stanowi wprost o „rejestrach dłużników”, a jedynie o „ujawnianiu informacji” przez biura informacji gospodarczej. $Z$ uwagi jednak na to, że w praktyce owe „ujawnianie informacji” uzyskuje właśnie formę rejestrów dłużników, w dalszej części opracowania będziemy posługiwać się właśnie takim określeniem.

Zgodnie $z$ ustawą biura takie prowadzone mogą być wyłącznie w formie spółki akcyjnej, a ich przedmiotem działalności jest pośrednictwo w udostępnianiu informacji gospodarczych, polegające na przyjmowaniu takich informacji od wierzycieli, ich przechowywaniu oraz ujawnianiu. Biura takie podlegają nadzorowi ministra właściwego do spraw gospodarki, za wyjątkiem kwestii związanych z przetwarzaniem danych osobowych ${ }^{6}$. Wśród ujawnianych informacji gospodarczych możemy zgodnie $z$ ustawą wyróżnić choćby dane dotyczące istniejącego zobowiązania pieniężnego, m.in. w zakresie wysokości zaległości, tytułu prawnego, jak również danych identyfikujących samego dłużnika.

W chwili obecnej funkcjonują w Polsce cztery biura informacji gospodarczej:

- BIG InfoMonitor S.A.,

- Krajowy Rejestr Długów Biuro Informacji Gospodarczej S.A.,

- Rejestr Dłużników ERIF Biuro Informacji Gospodarczej S.A.,

- Krajowe Biuro Informacji Gospodarczej S.A. ${ }^{7}$

Każde $z$ tych biur prowadzi własny, odrębny od pozostałych rejestr długów, które są niezależne zarówno względem siebie, jak i rejestrów publicznych. Dlatego też w każdym z nich z osobna mogą być ujawnione informacje odnośnie do dłużników niewywiązujących się ze swoich zobowiązań.

Ratio legis ustawodawcy dopuszczającego prowadzenie podobnego rodzaju działalności obejmowało bowiem przede wszystkim

\footnotetext{
5 Dz.U. 2010 r. Nr 81 poz. 530 ze zm., w skrócie u.u.i.g.w.d.g.

6 Art. 5 ust. 1,7 ust. 1 oraz 31 ust. 1 u.u.i.g.w.d.g.

7 http://www.mg.gov.pl/Prawo+dla+przedsiebiorcy/Informacja+gospodarcza (dostęp: 26.01.2016 r.)
} 
udostępnienie wierzycielom instrumentu, który doprowadzi do skrócenia terminów spłaty zobowiązań w obrocie gospodarczym. Motywem ustawodawcy była również niska popularność publicznych rejestrów dłużników, które $\mathrm{w}$ związku $\mathrm{z}$ tym nie spełniały należycie swojego zadania ${ }^{8}$. Takie rejestry, ukazujące nielojalność postępowania dłużnika, umożliwiają bowiem weryfikację jego wypłacalności np. przez banki badające zdolność kredytową danej osoby. Utrudnienia $z$ tym związane stanowią zaś dodatkową motywację dla dłużnika w spłacaniu zaległych zobowiązań. W literaturze pojawił się pogląd, że podobne rozwiązania miało stanowić wręcz swoisty „eksperyment formalny” w zbadaniu użyteczności podobnego instrumentu, mając na względzie przede wszystkim niewydolność wymiaru sprawiedliwości oraz swoiste społeczne przyzwolenie na nieregulowanie zobowiązań przez dłużników ${ }^{9}$.

Należy przyznać, że w praktyce rejestry prowadzone przez wymienione biura faktycznie odgrywają rolę dodatkowej formy nacisków na nielojalnych dłużników. $Z$ danych udostępnianych przez BIG-y korzystają bowiem np. wspomniane wcześniej banki czy inne instytucje kredytowe. W praktyce zaś ujawnienie istniejącej zaległości w którymkolwiek rejestrze długów prowadzi niejednokrotnie do tego, że dłużnik, doświadczając odmowy np. udzielenia kredytu lub pożyczki, rzeczywiście staje się znacznie bardziej skłonny do dobrowolnego uregulowania ciążącego na nim zobowiązania $^{10}$. Dopóki zaś zobowiązanie istnieje $\mathrm{e}^{11}$, wierzyciel ma prawo wnioskować o jego ujawnienie w którymkolwiek z prywatnych rejestrów. W przypadku drobniejszych roszczeń może to częstokroć stanowić znacznie szybciej działającą formą nacisku aniżeli nawet groźba postępowania sądowego. Zaznaczmy bowiem, że

8 Zob. uzasadnienie do projektu ustawy o udostępnianiu informacji gospodarczej, Sejm IV kadencji, druk nr 588, z dnia 6 czerwca 2002 r.

9 B. Bińkowska-Artowicz, Informacja gospodarcza. Informacja kredytowa, LEX 2014.

10 A. Bieć, Ocena rozwoju polskiego rynku informacji gospodarczych, Warszawa 2008, s. 16.

11 Ujawnianie spłaconych zobowiązań, a więc zobowiązań wygasłych jest niedopuszczalne i obwarowane sankcją w postaci kary pieniężnej w wysokości do $30000 \mathrm{zł}$ - zob. art. 47 u.u.i.g.w.d.g. 
np. przy spełnieniu warunków wymaganych dla ujawnienia przez BIG zadłużonego konsumenta ${ }^{12}$, wierzyciel nie musi dysponować tytułem wykonawczym do umieszczenia informacji $\mathrm{w}$ rejestrze dłużników.

Ustawa o u.i.g.w.d.g. wskazuje bowiem, że informacją gospodarczą jest również tytuł prawny, z którego wynika zobowiązanie pieniężne, jednakże w celu przyjęcia informacji do rejestru nie wymaga $\mathrm{w}$ tym wypadku posiadania tytułu wykonawczego, którym jak wiemy, będzie przede wszystkim orzeczenie sądu stanowiące tytuł egzekucyjny ${ }^{13} \mathrm{Z}$ nadaną klauzulą wykonalności. $Z$ pewnością jest to jeden $z$ czynników przesądzających o wyższej popularności prywatnoprawnych rejestrów długów od choćby rejestru dłużników niewypłacalnych w Krajowym Rejestrze Sądowym ${ }^{14}$.

\section{Ujawnianie w charakterze informacji gospodarczej roszczeń przedawnionych w rejestrach prowadzonych przez biura informacji gospodarczej}

Na kanwie wspomnianych regulacji warto zatem przyjrzeć się problemowi praktycznemu, jakim jest ujawnianie przedawnionych roszczeń cywilnoprawnych w rejestrach prowadzonych przez BIG-i. W pierwszej kolejności zaznaczmy, że w obecnym stanie prawnym upublicznianie w ten sposób informacji odnośnie do zobowiązań naturalnych pozostaje jak najbardziej prawnie dopuszczalne. Ustawodawca nie wprowadził bowiem zastrzeżenia, że ujawnione w rejestrze mogą być wyłącznie roszczenia nieprzedawnione. Do wymogów przewidzianych dla ujawniania zadłużenia konsumentów należy m.in. to, aby zobowiązanie wynikało $z$ określonego stosunku prawnego, np. umowy o udzieleniu kredytu konsumenckiego. Ustawodawca nie wprowadza jednak katalogu zamkniętego potencjalnych stosunków prawnych wchodzących tutaj w grę. Ważne

\footnotetext{
12 Zob. art. 14 ust. 1 u.u.i.g.w.d.g.

13 Zob. art. 777 Ustawy z dnia 17 listopada 1964 r. - Kodeks postępowania cywilnego (Dz.U. 1964 r. Nr 43 poz. 296 ze zm.) - w skrócie k.p.c.

14 Art. 55 i następne Ustawy z dnia 20 sierpnia 1997 r. o Krajowym Rejestrze Sądowym (Dz.U. 1997 r. Nr 121, poz. 770 ze zm.).
} 
jedynie, aby był to stosunek prawny „określony”, a więc powstały w wyniku łączącego wierzyciela oraz dłużnika konkretnego węzła prawnego, wynikającego $z$ umowy lub $z$ innej czynności prawnej ${ }^{15}$. Łączna kwota zobowiązań opiewać powinna na kwotę co najmniej 200 zł, a od wysłania wezwania do zapłaty listem poleconym upłynąć powinien co najmniej miesiąc. Jedynym temporalnym wymogiem jest to, aby roszczenie było wymagalne od co najmniej $60 \mathrm{dni}$, jednakże brak tutaj górnej granicy czasu po powstaniu stanu wymagalności roszczenia ${ }^{16}$. Widzimy więc, że wpisowi podlegać może bardzo rozległy katalog zobowiązań, zwłaszcza jeśli weźmiemy pod uwagę, jak niski próg kwotowy wchodzi tutaj w grę.

Tym samym brak ograniczeń co do możliwości ujawniania w rejestrach zobowiązań naturalnych rodzi dość daleko idące konsekwencje. $Z$ czysto formalnego punktu widzenia można by wstępnie uznać, że podobnego rodzaju praktyka nie narusza ściśle rozumianej istoty instytucji przedawnienia. Dłużnik w dalszym ciągu może skutecznie bronić się przed egzekwowaniem roszczenia $\mathrm{w}$ drodze przymusu państwowego, albowiem wpisanie zobowiązania naturalnego do jakiegokolwiek rejestru długów w żaden sposób nie pozbawia dłużnika możliwości podniesienia zarzutu przedawnienia. Jest to tym bardziej istotne, jeśli uwzględnimy, że zarzut przedawnienia może zostać uwzględniony wyłącznie na wniosek dłużnika, a nigdy $z$ urzędu ${ }^{17}$. W dalszym ciągu to formalnie dłużnik pozostaje podmiotem decydującym o losie przedawnionego roszczenia. Może zarówno podnosić zarzut przedawnienia, zrzekać się go czy dokonać zaspokojenia roszczenia, niezależnie od tego, czy wytoczono mu proces cywilny, czy też nie ${ }^{18}$.

15 A. Marzec, Komentarz do art. 14 ustawy o udostępnianiu informacji gospodarczych i wymianie danych gospodarczych, w: T. Białek, A. Marzec, Ustawa o udostępnianiu informacji gospodarczych i wymianie danych gospodarczych. Komentarz, Warszawa LEX 2011.

16 Art. 14 u.u.i.g.w.d.g.

17 Inaczej było w stanie prawnym sprzed 1 października $1990 \mathrm{r}$. W tym dniu weszła w życie nowelizacja kodeksu cywilnego z dnia 28 lipca 1990 r., która wprowadziła regułę uwzględniania zarzutu przedawnienia jedynie na zarzut dłużnika. Przed wejściem w życie nowelizacji zarzut przedawnienia roszczenia cywilnoprawnego był uwzględniany przez sąd $z$ urzędu.

18 A. Szpunar, Uwagi o zrzeczeniu się przedawnienia, „Rejent” 2002, nr 10, s. 13. 
Musimy również pamiętać, że samo ujawnienie w rejestrze długów zobowiązania naturalnego nie odbiera mu cechy „niezaskarżalności”. Co więcej, mimo że zobowiązanie naturalne korzysta ze znacznie uszczuplonej ochrony prawnej, to pozostaje prawnie istniejące i nie możemy uznać, aby roszczenia $z$ niego wynikające wygasły wskutek upływu okresu przedawnienia. Oznacza to, że ujawnienie obligatio naturalis $\mathrm{w}$ rejestrze $\mathrm{w}$ żaden sposób nie narusza zakazu ujawniania zobowiązań nieistniejących za pośrednictwem BIG-ów.

Czy możemy zatem przyjąć, że brak ograniczeń co do ujawniania zobowiązań naturalnych przez BIG zasługuje na pełną aprobatę? Otóż chyba nie do końca. Nie ma co prawda wątpliwości co do tego, że ujawnienie zobowiązania w rejestrze nie ma przełożenia na bezpośrednie możliwości egzekwowania roszczeń, tj. w szczególności w drodze procesu cywilnego oraz postępowania egzekucyjnego. Jednak $\mathrm{z}$ samej istoty oraz ratio legis regulacji zawartych w u.u.i.g.w.d.g wynika, że rejestry prowadzone przez BIG stanowią bardzo poważny i - nie ukrywajmy - dość skuteczny środek niejako „pośredniego egzekwowania” ujawnionych w ten sposób roszczeń.

Może to być szczególnie uciążliwy instrument nacisku np. dla konsumentów podejmujących starania dla uzyskania kredytu hipotecznego, w przypadku którego banki $z$ natury rzeczy badają historię kredytową potencjalnego kredytobiorcy ze szczególną starannością. W takiej sytuacji nawet ujawnienie stosunkowo niewielkiego długu za pośrednictwem BIG może być dużym utrudnieniem lub nawet stanowić podstawę odmowy udzielenia kredytu. Możemy zatem spotkać się w praktyce $z$ sytuacją, w której dłużnik, np. starający się o zawarcie umowy kredytu hipotecznego na zakup mieszkania, poddany takiemu środkowi nacisku będzie zmuszony zrezygnować z możliwości powołania się na zarzut przedawnienia. Ureguluje on zatem przedawnione zobowiązanie tylko dlatego, że zostało ujawnione w rejestrze dłużników, wpływając negatywnie na postrzeganie jego zdolności kredytowej.

Czy możemy uznać taką sytuację za w pełni zgodną może nie tyle nawet $z$ literą, ile $z$ ratio legis instytucji przedawnienia? Pamiętajmy, że jego podstawowy cel sprowadza się do usunięcia stanu niepewności prawnej w sytuacji, gdy uprawniony podmiot przez 
bardzo długi czas nie wykonuje swoich praw podmiotowych ${ }^{19}$. Przyjmujemy zatem, że nazbyt długa bezczynność wierzyciela uzasadnia niejako uznanie wyższości interesu dłużnika nad interesem wierzyciela. Tutaj natomiast, mimo że ustawodawca w praktyce odbiera wierzycielowi najskuteczniejszy (przynajmniej w zamyśle) instrument egzekwowania roszczenia w drodze przymusu państwowego, umożliwia mu skorzystanie $z$ instrumentu dającego, powiedzmy, możliwość „pośredniego” egzekwowania roszczenia $\mathrm{w}$ dodatku w praktyce w pewnych sytuacjach niewiele mniej skutecznego.

Co więcej, zwróćmy uwagę na to, że dla ujawnienia informacji gospodarczych w tym trybie nie ma konieczności spełnienia jakichś szczególnie wyśrubowanych wymogów dowodowych. Owszem - ujawnianie w rejestrze nieistniejących (np. spłaconych) zobowiązań obwarowane jest rzeczywiście pewnym sankcjami. $Z$ drugiej jednak strony groźba sankcji nie musi wcale być równie restrykcyjnym środkiem zaradczym jak wyśrubowane wymogi dowodowe. Musimy zaś mieć w szczególności na względzie to, że po upływie długiego okresu (a zwłaszcza po upływie okresu przedawnienia) dłużnicy bardzo często nie przechowują dowodów ewentualnej spłaty i wygaśnięcia zobowiązań, co dodatkowo ułatwia nieuczciwym wierzycielom korzystanie $z$ tego instrumentu. Dłużnik zaś nie może bronić się przed wpisem do rejestru dłużników, podnosząc zarzut przedawnienia, który chroniłby go w ewentualnym procesie. Ponadto wierzytelności ujawniane $\mathrm{w}$ rejestrach częstokroć przysługiwać będą podmiotom o, powiedzmy, bardzo silnej pozycji ekonomicznej (jak choćby wspominane kilkukrotnie banki), dla których groźba grzywny w wysokości maksymalnie 30000 zł może nie być aż tak odstraszająca. W praktyce zatem ochrona udzielona dłużnikowi, stanowiąca konsekwencję instytucji przedawnienia, ulega de facto uszczupleniu ze względu na istnienie legalnego instrumentu umożliwiającego wymuszenie realizacji przedawnionego roszczenia.

19 A. Jedliński, Komentarz do art. 117, w: Kodeks cywilny. Komentarz, t. 1: Część ogólna, red. A. Kidyba, wyd. 2, Warszawa LEX 2012. 
Podsumowując, możemy właściwie stwierdzić, że dłużnikowi przysługują w omawianej przez nas sytuacji mniejsze uprawnienia i możliwości „obrony” niż przysługiwałyby mu w procesie sądowym. Pomijając już nawet kwestię przedawnienia, wspomniane w poprzednim akapicie trudności dowodowe dłużników (przed którymi właśnie przedawnienie m.in. ma w zamyśle chronić) mogą przecież stanowić znaczne pole do nadużyć dla wierzycieli, którzy nie dysponują nawet wierzytelnością wobec dłużnika, ale potrafią wykorzystać to, że nie jest on w stanie udowodnić nieistnienia zobowiązania.

\section{Postulaty odnośnie do nieujawniania w rejestrach dłużników}

\section{przedawnionych roszczeń cywilnoprawnych}

\section{a zatarcie skazania na gruncie prawa karnego}

Zastanówmy się zatem, w jaki sposób należałoby potraktować instytucję przedawnienia roszczeń, jeśli przyjmiemy, że obecny stan prawny istniejący w u.u.i.g.w.d.g. nie do końca pozostaje zbieżny $\mathrm{z}$ ratio legis tej instytucji. Dla oceny owego zagadnienia warto dokonać jego analizy również pod kątem systemowym, w stosunku do innych dziedzin polskiego prawa.

Najbliższym naszych rozważań będzie chyba odniesienie się do instytucji zatarcia skazania występującej na gruncie prawa karnego. Istnieje tam bowiem rejestr (tzw. krajowy rejestr karny - w skrócie k.r.k.), w którego zasobach przechowywane oraz ujawniane są informacje odnośnie do osób, które zostały m.in. prawomocnie skazane $z$ tytułu przestępstw przewidzianych przez kodeks karny $^{20}$ czy kodeks karny skarbowy ${ }^{21}$, były poszukiwane listem gończym, tymczasowo aresztowane itd. ${ }^{22}$

20 Ustawa z dnia 6 czerwca 1997 r. - Kodeks karny (Dz.U. 1997 r. Nr 88, poz. 553 ze zm.).

${ }^{21}$ Ustawa z dnia 10 września 1999 r. Kodeks karny skarbowy (Dz.U. 1999 r. Nr 83, poz. 930 ze zm.).

22 Zob. art. 1 ustawy z dnia 24 maja 2000 r. o Krajowym Rejestrze Karnym (Dz.U. 2000 r. Nr 50, poz. 580 ze zm.). 
Zgodnie $\mathrm{z}$ kodeksem karnym istotą zatarcia skazania jest to, że po upływie danego okresu czasu samo skazanie uważa się za niebyłe, a wpis do k.r.k. ulega wykreśleniu. Kwestia ta pozostaje bardzo istotna $z$ tego względu, że sam wpis do k.r.k. możemy w pewnym sensie traktować jako swoisty dodatkowy sposób napiętnowania skazanego. Instytucja ta ma zatem na celu eliminację trwałego charakteru negatywnych następstw skazania (a głównie efektu stygmatyzacji) i umożliwienie sprawcy powrotu do pełnoprawnego funkcjonowania w społeczeństwie ${ }^{23}$. Do samego zatarcia skazania dochodzi natomiast $z$ mocy samego prawa, postanowienia sądu lub na mocy aktu łaski Prezydenta RP.

Zastanówmy się zatem, czy w świetle rozważanego przez nas problemu nie byłoby celowe wprowadzenie instytucji podobnej do instytucji zatarcia skazania również na gruncie regulacji rejestrów dłużników. Możemy bowiem przyjąć, że rejestr dłużników, podobnie jak k.r.k., ma w pewnym sensie stanowić poświadczenie braku wiarygodności danej osoby - z tym że w przypadku rejestru dłużników w zakresie jej rzetelności w spełnianiu zobowiązań cywilnoprawnych, natomiast w zakresie k.r.k. - w zakresie skłonności danej osoby do zachowań przestępczych. Oczywiście trudno przeczyć, że doniosłość problemu pozostaje jednak większa w przypadku rejestru karnego, jednakże nie oznacza to, że w kwestii rejestrów dłużników problem w ogóle nie zasługuje na uwzględnienie.

Jeśli spojrzymy zaś na zagadnienie pod tym właśnie kątem, możemy nagle stwierdzić, że pomimo zupełnej odmienności źródłowych dziedzin prawa, między zatarciem skazania, a jego postulowanym odpowiednikiem na gruncie prawa cywilnego istniałyby zasadnicze aksjologiczne punkty styczne. Obie te instytucje miałyby wszak na celu uwzględnienie interesów zainteresowanego (tj. dłużnika lub skazanego), co do którego dochodziłoby do uznania za niebyłe jego negatywne zachowanie w przeszłości ze względu na upływ czasu. Oczywiście na gruncie cywilnoprawnym skutek taki miałby dotyczyć jedynie samego wykreślenia $z$ rejestru, a nie całkowitego wygaśnięcia zobowiązania. Skoro zatem ustawodawca,

23 M. Mozgawa, Komentarz do art. 106, w: Kodeks karny. Komentarz, red. M. Mozgawa, wyd. 7, Warszawa LEX 2015. 
przewidując istnienie na gruncie prawa karnego k.r.k., dopuszcza usunięcie $z$ jego zasobów informacji odnośnie do danego skazanego po pewnym upływie czasu, to powstaje pytanie, dlaczego nie moglibyśmy uznać zasadności podobnej regulacji na gruncie prawa cywilnego i rejestrów dłużników.

\section{Działania Rzecznika Praw Obywatelskich oraz projekty zmian ustawowych}

Problem ujawniania przez BIG-i przedawnionych roszczeń został już wcześniej dostrzeżony, m.in. przez Rzecznika Praw Obywatelskich. W wystąpieniu skierowanym w 2013 r. $^{24}$ pod adresem wiceministra gospodarki rzecznik wskazała właśnie na istnienie przytoczonego powyżej problemu. Podniesiono, że takie ukształtowanie regulacji u.u.i.g.w.d.g (w szczególności art. 4) prowadzi sytuacji, w której wierzyciele, korzystając często z usług firm windykacyjnych, wykorzystują rejestry dłużników dla wymuszania spłaty przedawnionych roszczeń, omijając w ten sposób sądowy tryb dochodzenia spłaty zobowiązań. RPO powołała się jednocześnie na istnienie praktyk rynkowych polegających na publicznym udostępnianiu przedawnionych wierzytelności, oferujących sprzedaż za pośrednictwem internetowych giełd wierzytelności. Duża skala zjawiska tym bardziej przemawia zatem za koniecznością legislacyjnego rozwiązania owego problemu przez ustawodawcę.

Niejako w następstwie wystąpienia rzecznik pojawiły się projekty nowelizacji u.u.i.g.w.d.g, również w zakresie dopuszczalności ujawniania przez BIG przedawnionych wierzytelności. Niestety działania te nie wyszły jak dotąd poza fazę projektową oraz konsultacji społecznych ${ }^{25}$. Założenia jednak uwzględniają argumentację przedstawioną przez Rzecznika Praw Obywatelskich, zakładając wprowadzenie regulacji statuującej obowiązek wykreślenia $z$ rejestru prowadzonego przez BIG roszczeń przedawnionych, skiero-

\footnotetext{
24 http://www.sprawy-generalne.brpo.gov.pl/pdf/2013/05/735416/1747562. pdf (dostęp: 24.01.2016 r.)

25 http://konsultacje.gov.pl/node/3446 (dostęp: 24.01.2016 r.)
} 
wanych przeciwko konsumentowi. Proponowane rozwiązania obejmują wykreślenie wpisu $z$ rejestru np. po roku od upływu okresu przedawnienia, który powinien zostać obowiązkowo ujawniony $\mathrm{w}$ rejestrze już na etapie zgłoszenia istnienia zaległego zobowiązania do samego rejestru.

\section{Uwagi de lege ferenda}

Zastanówmy się zatem, jak zostać skonstruowana podobna regulacja powinna. W szczególności kwestią nieco kontrowersyjną pozostawać może to, po jakim czasie od upływu okresu przedawnienia dane zobowiązanie powinno zostać wykreślone $z$ rejestru lub też BIG powinien odmówić jego ujawnienia. Rozważmy więc, czy powinno to następować natychmiast po przedawnieniu roszczenia, czy też stosowniejsze byłoby oznaczenie określonego terminu po upływie terminu przedawnienia, np. rocznego, który pojawia się wśród propozycji projektowych.

Jeśli w rozstrzygnięciu tej kwestii brać pod uwagę regulacje dotyczące zatarcia skazania, być może warto byłoby rozważyć wprowadzenie różnych terminów, również dla wykreślenia danego roszczenia $z$ rejestru prowadzonego przez BIG. Przy zatarciu skazania bowiem okres, po którym dochodzi do wykreślenia danej osoby z k.r.k., uzależniony jest przede wszystkim od długości kary oraz rodzaju przestępstwa, za które została ona ukarana. Być może warto zatem również tutaj byłoby wprowadzić podobne rozróżnienie w zależności np. od kwoty, na jaką opiewa zaległość danego dłużnika. Owszem - przedawnienie roszczenia wywołuje ten sam efekt i przekształca zobowiązanie w obligatio naturalis niezależnie od wysokości roszczenia. Jednak w dalszym ciągu należy również mieć na względzie swoistą funkcję ochronną rejestrów dłużników (którą pełnią nawet rejestry prywatnoprawne), jaką jest nie tylko motywacja do spłaty zobowiązań dla wierzycieli rzeczywistych, ale również ochrona wierzycieli potencjalnych przed zawarciem umowy z dłużnikiem niewywiązującym się ze swoich zobowiązań. Można by zatem rozważyć, czy nie byłoby celowe, aby przykładowo dla roszczeń przedawnionych, opiewających na relatywnie niewielkie 
kwoty, wprowadzić regulację o obowiązku wykreśleniu z rejestru natychmiast lub po relatywnie krótkim czasie po upływie okresu przedawnienia, a dla roszczeń opiewających na wysokie kwoty po czasie nieco dłuższym. Niezależnie bowiem od konieczności uwzględnienia słusznych interesów dłużników nie możemy jednak całkowicie pomijać kwestii ochrony samych wierzycieli.

\section{STRESZCZENIE}

Przedawnienie roszczeń cywilnoprawnych

a zatarcie skazania w prawie karnym na tle prywatnych rejestrów dłużników w Polsce

- uwagi de lege lata i de lege ferenda

Tematem przedmiotowego artykułu są rozważania odnośnie do problemu ujawniania $\mathrm{w}$ rejestrach dłużników prowadzonych przez biura informacji gospodarczej dłużników, w stosunku do których wierzyciele dysponują przedawnionymi roszczeniami cywilnoprawnymi. W obecnym stanie prawnym ustawodawca w żaden sposób nie limituje możliwości ujawniania za pośrednictwem tzw. BIG-ów, powstałych w wyniku przedawnienia roszczeń, zobowiązań naturalnych. Biorąc natomiast pod uwagę jedną ze społecznych funkcji rejestrów dłużników, jaką pozostaje nie tylko ochrona potencjalnych wierzycieli przed zawieraniem umów $z$ niesolidnymi dłużnikami, ale również swoiste wymuszenie na dłużniku realizacji właśnie zobowiązań ujawnionych w rejestrze, powstaje pytanie odnośnie do zgodności takich unormowań $\mathrm{z}$ ratio legis instytucji przedawnienia w prawie cywilnym. W celu zobrazowania celowości postulowanych rozwiązań warto pokusić się o ich porównanie choćby $z$ instytucją zatarcia skazania występującą na gruncie prawa karnego. W świetle zarysowanych rozważań w niniejszym artykule podjęta zostanie zatem próba zarówno oceny obecnie obowiązujących unormowań, jak i sformułowania postulatów de lege ferenda.

Słowa kluczowe: przedawnienie; rejestr dłużników; ochrona dłużników i wierzycieli 


\section{SUMMARY}

The time bar of the civil claims compared to expungement in the criminal law in the context of the debtors register in Poland - de lege lata and de lege ferenda

The topic of the article are the considerations about the problem of disclosing the time barred claims in the debtors registers, conducted by the economic information bureaus. The Legislator doesn't limit an opportunity to disclose the obligationes naturales through this type of bureaus. However, we have to remember that the social function of the debtor's registers conducted by the economic information bureaus are not only the protection of potencial creditors, but also forcing the debtor to repay liabilities disclosed in the registers. From those reason arising the question about the compatibility of those regulations and ratiolegis of the claim's time bar. It is worth comparing eventual postulated changes of the regulations with the expungement in the criminal law. To sum up, the aim of the article is the rating of the current regulations and formulating eventual de lege ferenda demands.

Key words: time bar; debtors register; protection of debtors and creditors

\section{BIBLIOGRAFIA}

Białek T., Marzec A., Ustawa o udostępnianiu informacji gospodarczych $i$ wymianie danych gospodarczych. Komentarz, Warszawa LEX 2011.

Bieć A., Ocena rozwoju polskiego rynku informacji gospodarczych, Warszawa 2008.

Bińkowska-Artowicz B., Informacja gospodarcza, informacja kredytowa, Warszawa LEX 2014.

Kidyba A. (red.), Kodeks cywilny. Komentarz, t. 1: Część ogólna, wyd. 2, Warszawa LEX 2012.

Mozgawa M (red.), Kodeks karny. Komentarz, wyd. 7, Warszawa LEX 2015. Osajda K. (red), Kodeks cywilny. Komentarz, t. 1, Warszawa 2013.

Ostrowski T., Ustawa o udostępnianiu informacji gospodarczych $i$ wymianie danych gospodarczych, Warszawa 2012.

Radwański Z., Olejniczak A., Zobowiązania-część ogólna, Warszawa 2014. Szpunar A., Uwagi o zrzeczeniu się przedawnienia, „Rejent”, nr 10, 2002. Wolter A., Ignatowicz J., Stefaniuk K., Prawo cywilne, Warszawa 1996. 
